\title{
Alle syke nyfødte bør få enkeltrom
}

\author{
Utgangspunktet for familiefokusert behandling er at foreldre er nødvendige omsorgspersoner for sine barn \\ under sykehusinnleggelse, ikke minst i nyfødtperioden. Det eksisterende kunnskapsgrunnlaget viser at enkelt- \\ rom for den syke nyfødte med foreldrene har fordeler sammenliknet med tradisjonelle åpne nyfødtavdelinger.
}

Foreldre opplever stress i forbindelse med barnets innleggelse i en nyfødtavdeling. Mye av dette kan forklares ved atskillelsen fra det nyfødte barnet $(1,2)$. Familiefokusert behandling er en retning innenfor nyfødtmedisin der man arbeider ut ifra holdninger om at foreldrene er de viktigste personene i barnets liv og at de derfor skal stå i første rekke i pleien av barnet. I hvilken utstrekning dette kan etterleves, avhenger av barnets medisinske tilstand og behandlingsbehov. Uavhengig av barnets tilstand skal familien alltid møtes med verdighet og respekt, og informasjon skal kommuniseres på en måte som inviterer til foreldres deltakelse i pleie og behandling. Det gir familien følelse av kontroll og uavhengighet.

Grunnprinsippene i familiefokusert behandling bygger i tillegg til verdighet og respekt, på informasjonsdeling, deltakelse og samarbeid (3). I dette ligger foreldres delaktighet ved innleggelse, under visitt, rapporter og ved akutte hendelser (2). Foreldre skal oppfordres til å være til stede $i$ avdelingen og det skal tilrettelegges for ubegrenset samvær med barnet (4). Dette er i samsvar med FNs barnekonvensjon (5) og forskrift om barns rettigheter i sykehus (6): «Barn har rett til å ha minst én av foreldrene hos seg under institusjonsoppholdet $i$ den grad det følger av pasient- og brukerrettighetsloven $\S 6-2$. Ved alvorlig/livstruende sykdom skal begge foreldrene få være hos barnet. Personalet plikter å avklare med foreldrene hvilke oppgaver foreldrene ønsker og kan utføre mens de er hos barnet.»

Likevel har atskillelse av foreldre og deres syke nyfødte barn vært normen, spesielt for de minste premature, også etter at foreldrenes rolle som omsorgspersoner i barnemedisin ellers ble erkjent. Tradisjonelle nyfødtavdelinger er utformet for å lette medisinsk behandling og pleie basert på en antakelse om at det er praktisk for helsepersonell å bevege seg $i$ et åpent landskap med pasienter liggende på rad og rekke. Det er vanlig med store intensivrom der inntil åtte innlagte barn og foreldrepar oppholder seg.

De siste årene er man blitt oppmerksom på den mulige negative påvirkningen store intensivrom har på de nyfødtes utvikling. Det åpne miljøet kjennetegnes ofte av støy, mindre skjerming av familien og muligens svakere tilknytning mellom foreldre og barn (7). Lenestol og foreldreseng ved siden av den nyfødtes seng samt foreldrerom i eller nær avdelingen mangler ofte. Privatliv og taushetsplikten utfordres (8). Derfor har flere begynt å revurdere utformingen av sine nyfødtavdelinger, først og fremst med tanke på pasientene, men også på familiene og helsepersonell. Både barneombudet (9) og helseministeren (10) har uttalt at økt tilretteleggelse for foreldres uhindrede tilstedeværelse sammen med sine syke barn er et krav som stilles til alle landets nyfødtavde-

\section{«Enkeltrom kan ha en rekke positive effekter for den nyfødte, for- eldrene og de ansatte»}

linger. I mai 2012 åpnet den nye nyfødtintensivseksjonen ved Vestre Viken, Drammen, som den første avdelingen i Norge som utelukkende behandler syke nyfødte i enkeltrom sammen med sine foreldre. Det er ønskelig med et slikt tilbud for alle landets syke nyfødte.

\section{Positive effekter av enkeltrom}

Ved Avdeling for nyfødte på Akershus universitetssykehus har vi i dag 23 sengeplasser for syke nyfødte fordelt på tre åpne stuer, med fem foreldrerom i avdelingen og fire foreldrerom i en underliggende etasje. I perioder er det ikke ledige foreldrerom, ingen av foreldrerommene har eget bad, og varme måltider må hentes i kantinen i den andre enden av sykehuset. Disse forholdene begrenser foreldrenes mulighet til å delta i barnets omsorg hele døgnet.

Vinteren 2012/13 så vi på ombyggingsmuligheter for å gjøre avdelingen mer familievennlig. På initiativ fra ledelsen i Barneog ungdomsklinikken utførte vi et systematisk litteratursøk etter Kunnskapssenterets modell for «mini-metodevurdering» av nye metoder eller behandlinger i helsevesenet (11). Metoden vi ville undersøke var enkeltrom som en isolert faktor sammenliknet med åpen nyfødtavdeling. En detaljert oversikt over litteratursøket og resultater finnes på Kunnskapssenterets hjemmesider (12).

Vi fant ni enkeltstudier vurdert som kvalitetsmessig tilfredsstillende. To randomiserte kliniske studier viste at enkeltrom ga redusert liggetid og risiko for kronisk lungesykdom (13), men det var ingen forskjell i stressrespons hos de nyfødte og mødrene (14) sammenliknet med åpen avdeling. Sju observasjonsstudier viste samlet færre dager til oppnådd full enteral ernæring, større andel ammende, færre apneer og sykehusinfeksjoner, større mestringsfølelse hos mødrene i forhold til tolking av barnets signaler samt mindre støy og fysisk belastning for helsepersonell i enkeltrom (15-21). Av negative konsekvenser ved enkeltrom er det påvist økt følelse av isolasjon blant pleiepersonell, i form av følelse av mindre kollegastøtte (20). Fedre har opplevelse av at mor og barn får redusert oppfølging (18).

Til tross for sparsomt kunnskapsgrunnlag konkluderer vi med at enkeltrom kan ha en rekke positive effekter for den nyfødte, foreldrene og de ansatte i nyfødtavdelingen. For en vellykket familiefokusert tilnærming er det i tillegg til fysisk tilrettelegging nødvendig å integrere familievennlige prinsipper og holdninger. Mangelfull oppnåelse av dette kan forklare de negative tilbakemeldingene, spesielt fra fedre, i en av de inkluderte observasjonsstudiene.

På Akershus universitetssykehus er det nå planlagt og budsjettert for tre enkeltrom fullt utstyrt for behandling av syke nyfødte, inkludert dem med behov for intensivbehandling. $\mathrm{Vi}$ vil gjøre en fortløpende evaluering og tilpasning av ombyggingen ut ifra pleiernes og legenes erfaringer. Personalets holdninger, kunnskap og evne til å utnytte de nye lokalene til å fremme tilknytning og samspill, samtidig som nødvendig overvåking og medisinsk forvarlighet ivaretas, er avgjørende for best mulig effekt av ombyggingen.

Vi vil oppfordre alle landets nyfødtavdelinger til å bruke våre erfaringer og kunnskapsgrunnlag og ha som langsiktig mål at alle syke nyfødte skal få behandling i eget rom sammen med sine foreldre.

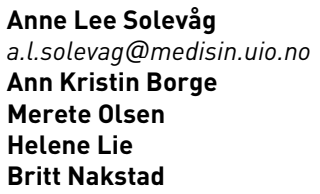

Anne Lee Solevåg (f. 1977) er spesialist i barnesykdommer, med doktorgrad i nyfødtmedisin.

Hun er overlege ved Avdeling for nyfødte,

Barne- og ungdomsklinikken, Akershus universitetssykehus. Hun er for tiden postdoktor ved University of Alberta, Canada.

Forfatter har fylt ut ICMJE-skjemaet og oppgir ingen interessekonflikter. 
Ann Kristin Borge (f. 1965) er sykepleier og leder av ressursgruppen for familiefokusert behandling ved Avdeling for nyfødte, Barneog ungdomsklinikken, Akershus universitetssykehus.

Forfatter har fylt ut ICMJE-skjemaet og oppgir ingen interessekonflikter.

Merete Olsen (f. 1964) er intensivsykepleier og var tidligere fagsykepleier ved Avdeling for nyfødte, Barne- og ungdomsklinikken, Akershus universitetssykehus.

Forfatter har fylt ut ICMJE-skjemaet og oppgir ingen interessekonflikter.

Helene Lie (f. 1974) er spesialbibliotekar ved Medisinsk bibliotek, Akershus universitetssykehus.

Forfatter har fylt ut ICMJE-skjemaet og oppgir ingen interessekonflikter.

Britt Nakstad (f. 1958) er spesialist i barnesykdommer med spesialkompetanse i nyfødtmedisin og er professor ved Barne- og ungdomsklinikken, Akershus universitetssykehus. Forfatter har fylt ut ICMJE-skjemaet og oppgir ingen interessekonflikter.

\section{Litteratur}

1. Affonso DD, Hurst I, Mayberry LJ et al. Stressors reported by mothers of hospitalized premature infants. Neonatal Netw 1992; 11: 63-70.
2. Griffin T. Family-centered care in the NICU. J Perinat Neonatal Nurs 2006; 20: 98-102

3. Menard SW, Park MK. Blood pressure measure ment in children: a brief review. Semin Perioper Nurs 1995: 4: $92-5$

4. Guidelines for perinatal care. 5. utg. Washington, DC: American Acedemy of Pediatrics \& American College of Obestetricians \& Gynecologists, 2002

5. De forente nasjoner. FNs konvensjon om barnets rettigheter. www.fn.no/Bibliotek/Avtaler/ Menneskerettigheter/FNs-konvensjon-om-barnetsrettigheter-Barnekonvensjonen (14.10.2014).

6. FOR-2000-12-01-1217. Forskrift om barns opphold i helseinstitusjon. http://lovdata.no/dokument/ SF/forskrift/2000-12-01-1217 (14.10.2014).

7. Johnson BH, Abraham MR, Parrish RN. Designing the neonatal intensive care unit for optimal family involvement. Clin Perinatol 2004: 31:353-82 ix . ix.

8. Nyqvist $\mathrm{KH}$, Häggkvist $\mathrm{AP}$, Hansen $\mathrm{MN}$ et al. Expansion of the ten steps to successful breastfeeding into neonatal intensive care: expert group recommendations for three guiding principles. J Hum Lact 2012; 28: 289-96.

9. Asheim K, Enerstedt V. Krever akutte grep ved nyfødt-intensiver. VG nett 6.3.2014. www.vg.no/ nyheter/innenriks/sykehus-norge/krever-akuttegrep-ved-nyfoedt-intensiver/a/10137780/ (14.10.2014).

10. NTB. Støre vil ha foreldrene tettere på de aller minste. VG nett 14.1.2013. http://www.vg.no/ nyheter/innenriks/helse/stoere-vil-ha-foreldrenetettere-paa-de-aller-minste/a/10049367/ (14.10.2014).

11. Norsk kunnskapssenter for helsetjenesten. www. helsebiblioteket.no/minimetodevurdering. (28.6.2014)

12. Nakstad B. Enkeltrom i familie-barn vennlig nyfødtavdeling. www.helsebiblioteket.no/ minimetodevurdering/sok (15.9.2014)

13. Ortenstrand A, Westrup B, Broström EB et al. The Stockholm Neonatal Family Centered Care Study: effects on length of stay and infant morbidity. Pediatrics 2010; 125: e278-85.
14. Mörelius E Broström EB, Westrup B et al. The Stockholm Neonatal Family-Centered Care Study effects on salivary cortisol in infants and their mothers. Early Hum Dev 2012; 88: 575-81.

15. Domanico R, Davis DK, Coleman F et al. Documenting the NICU design dilemma: parent and staff perceptions of open ward versus single family room units. J Perinatol 2010; 30: 343-51.

16. Domanico R, Davis DK, Coleman F et al. Documenting the NICU design dilemma: comparative patient progress in open-ward and single family room units. J Perinatol 2011; 31: $281-8$.

17. Erdeve O, Arsan S, Canpolat FE et al. Does individual room implemented family-centered care contribute to mother-infant interaction in preterm deliveries necessitating neonatal intensive care unit hospitalization? Am J Perinatol 2009; 26: 159-64.

18. Hildingsson I, Thomas J, Olofsson RE et al. Still behind the glass wall? Swedish fathers' satisfaction with postnatal care. J Obstet Gynecol Neonatal Nurs 2009; 38: 280-9.

19. Stevens DC, Helseth CC. Khan MA et al. A comparison of parent satisfaction in an open-bay and single-family room neonatal intensive care unit. HERD 2011; 4: 110-23.

20. Stevens DC, Helseth CC, Thompson PA et al. A comprehensive comparison of open-bay and single-family-room neonatal intensive care units at Sanford Children's Hospital. HERD 2012; 5 23-39.

21. Wataker H, Meberg A, Nestaas E. Neonatal family care for 24 hours per day: effects on maternal confidence and breast-feeding. J Perinat Neonatal Nurs 2012; 26: 336-42.

Mottatt 1.9. 2014, første revisjon innsendt 17.9. 2014, godkjent 3.10. 2014. Redaktør: Hanne Støre Valeur.

Publisert først på nett. 